\title{
Machaerium (Leguminosae, Papilionoideae, Dalbergieae) nos estados de Mato Grosso e Mato Grosso do Sul, Brasil
}

\author{
Machaerium (Leguminosae, Papilionoideae, Dalbergieae) from the Mato Grosso \\ and Mato Grosso do Sul States, Brazil
}

Caroline do Amaral Polido ${ }^{1} \&$ Ângela Lúcia Bagnatori Sartori ${ }^{2}$

\begin{abstract}
Resumo
Neste estudo, são confirmados 18 táxons de Machaerium para Mato Grosso e Mato Grosso do Sul. Dos 15 táxons ocorrentes em Mato Grosso, seis são citados pela primeira vez no Estado: M. biovulatum, M. floribundum var. floribundum, M. macrophyllum var. macrophyllum, M. paraguariense, M. quinatum var. parviflorum e $M$. quinatum var. quinatum. Das nove espécies ocorrentes no Mato Grosso do Sul, M. eriocarpum e M. isadelphum são novas ocorrências para o Estado. O gênero encontra-se amplamente distribuído nos Estados e está representado em diversas formações vegetacionais. São apresentadas chave analítica, descrições e informações sobre a fenologia e os ambientes preferenciais de cada táxon, além de ilustrações para determinados táxons.
\end{abstract}

Palavras-chave: Centro-Oeste, Fabaceae, florística, Jacarandá, taxonomia.

\begin{abstract}
In this study, 18 taxa of Machaerium are confirmed for Mato Grosso and Mato Grosso do Sul. Amongst the 15 taxa occurring in Mato Grosso, six were cited for the first time in the State: M. biovulatum, M. floribundum var. floribundum, M. macrophyllum var. macrophyllum, M. paraguariense, M. quinatum var. parviflorum, and M. quinatum var. quinatum. Amongst the nine species confirmed for Mato Grosso do Sul, M. eriocarpum and M. isadelphum are new records for the State. The genus is widely distributed in the States and is represented in various vegetational formations. Analytical key, descriptions, and information on the phenology and preferential environments of each taxon are presented, besides illustrations for certain taxa.
\end{abstract}

Key words: Center-West Brazil, Fabaceae, floristics, Jacarandá, taxonomy.

\section{Introdução}

Machaerium Pers. é um dos maiores gêneros arbóreos tropicais de Papilionoideae (Leguminosae), com cerca de 130 táxons, distribuídos do México à Argentina, com centro de diversidade no Brasil (Lewis et al. 2005). Em geral, espécies do gênero são popularmente conhecidas como jacarandás ou caviúnas, e apresentam importância econômica e ecológica, sendo utilizadas para a recomposição de áreas degradadas (Lorenzi 1992, 1998; Pott \& Pott 1994).

Diversos trabalhos foram realizados com Machaerium no Brasil (Bentham 1862; Hoehne 1941; Bastos 1987; Lewis 1987; Lima et al. 1994; Mendonça-Filho 1996; Dubs 1998; Sartori \& Tozzi 1998; Bortoluzzi et al. 2004; Camargo, 2005; Lima et al. 2007; Mendonça-Filho et al. 2007; Polido \& Sartori 2007). Estudos florísticos e fitossociológicos ainda são incipientes em Mato Grosso e Mato Grosso do Sul, porém confirmam a ampla distribuição do gênero e sua importante representatividade nas diferentes formações vegetacionais (Pinto \& OliveiraFilho 1999; Damasceno Junior et al. 2000; Marimon \& Lima 2001; Salis et al. 2004; Borges \& Shepherd 2005; Daniel \& Arruda 2005; Pinto \& Hay 2005). Os objetivos deste estudo foram realizar o levantamento das espécies de Machaerium ocorrentes em Mato Grosso e Mato Grosso do Sul e fornecer chave analítica, descrições, ilustrações e informações sobre a floração, a frutificação e os ambientes preferenciais de cada táxon.

\footnotetext{
${ }^{1}$ Universidade Estadual de Campinas, Instituto de Biologia, Depto. Biologia Vegetal, Programa de Pós-Graduação em Biologia Vegetal, C.P. 6109, 13083-970, Campinas, SP

${ }^{2}$ Universidade Federal de Mato Grosso do Sul,Centro de Ciências Biológicas e da Saúde, Depto. Biologia, Programa de Pós-Graduação em Biologia Vegetal, C.P. 549, 79070-900, Campo Grande, MS. Autora para correspondência: albsartori@gmail.com
} 


\section{Material e Métodos}

Foram examinadas 210 exsicatas depositadas nos herbários nacionais, além de materiais-tipo ou foto de tipos disponíveis. A sigla dos herbários segue Holmgren \& Holmgren (1998). As plantas foram identificadas a partir da literatura e de comparações. A chave de identificação e as descrições foram baseadas nas análises morfológicas de espécimes coletados nos dois Estados, complementadas pelas informações dos coletores e observações em campo. Para espécies que não apresentavam flores e frutos foram utilizados dados de bibliografias específicas. A terminologia morfológica adotada nas descrições foi baseada em Font Quer (1953), Hickey (1973), Radford et al. (1974), Harris \& Harris (1994) e Barroso et al. (1999). As mensurações foram feitas com paquímetro digital. Informações a respeito do período reprodutivo, distribuição geográfica e ambiente preferencial das espécies foram obtidas das etiquetas de herbário, consulta bibliográfica e observações em campo. As formações vegetacionais foram classificadas de acordo com o IBGE (1992).

Foram ilustrados os 10 táxons não incluídos no levantamento de Machaerium para o Pantanal (Polido \& Sartori 2007). As ilustrações foram realizadas a partir de material herborizado e hidratado, com auxílio de câmara-clara acoplada a estereomicroscópio Zeiss.

\section{Tratamento Taxonômico}

Machaerium Pers., Syn. pl. 2: 276. 1807. Tipo: M. ferrugineum (Willd.) Pers.

Árvore, arvoreta, arbusto a liana; ramos geralmente com sulcos longitudinais, raramente transversais (M. villosum); estípulas quando transformadas em espinhos persistentes, aos pares na base da folha; lenticelas e exsudado em geral presentes; catáfilos raramente evidentes (M. villosum). Folhas imparipinadas, sem estipela; folíolos sésseis, subsésseis ou pedicelados, alternos ou subopostos, concolores ou discolores, de formas variadas, nervação broquidódroma ou craspedódroma. Inflorescências paniculadas ou racemosas, axilares e/ou terminais; brácteas geralmente caducas. Flores sésseis, subsésseis ou pediceladas; bractéolas adpressas ao cálice; cálice campanulado ou cilíndrico, 5 lacínios; corola de diversas colorações; estandarte às vezes com mácula amarela, alva ou creme na base; asa com unguícula linear, esculturas difusas, com dobras na face ventral; pétalas da quilha conatas dorsalmente, elípticas ou oblongas; estames 10, raramente 8 (M. acutifolium), monadelfos, raramente em duas falanges pentâmeras $(M$. aculeatum, $M$. hirtum, $M$. isadelphum), diadelfos (M. brasiliense), filetes de alturas iguais ou diferentes, glabros, anteras elípticas, oblongas, ovadas ou triangulares, dorsifixas, introrsas; ovário estipitado, uniovulado, com disco nectarífero anelar na base, estigma capitado ou clavado. Fruto sâmara, cultriforme ou falciforme, estipitado, região seminífera basal, asa apical, reticulada, raramente legume samaroide (M. inundatum).

\section{Chave para os táxons de Machaerium ocorrentes em Mato Grosso e Mato Grosso do Sul}

1. Folíolos com nervação broquidódroma.

2. Folhas com 19 ou mais folíolos

18. M. villosum

2'. Folhas com menos de 19 folíolos.

3. Folíolos ovados ou largo-ovados, raramente largo-elípticos.

4. Folíolos de ápice acuminado, inflorescências paniculadas, frutos legumes samaroides 9. M. inundatum

4. Folíolos de ápice cuspidado a raramente acuminado, inflorescências racemosas, frutos sâmaras 13. M. paraguariense

3'. Folíolos lanceolados, oblongo-lanceolados, oblongo-elípticos ou oval-lanceolados.

5. Pecíolo e raque vilosos a esparso-vilosos 5. M. brasiliense

5'. Pecíolo e raque nunca vilosos a esparso-vilosos.

6. Folhas 5-foliolada, cálice viloso, bractéola ovada

11. M. macrophyllum var. macrophyllum

6'. Folha 9-17-foliolada, cálice glabrescente, tomentoso no ápice, bractéola geralmente ovado-comprimida. 
7. Pecíolo pubescente a glabro, folíolos em geral lanceolados ou oblongo-lanceolados, região seminífera mais que $3 \mathrm{~cm}$ compr

7'. Pecíolo tomentoso a glabrescente, folíolos em geral elípticos, região seminífera menos que $3 \mathrm{~cm}$ compr.

17. M. stipitatum

1'. Folíolos com nervação craspedódroma.

8. Estípulas não modificadas em espinhos.

9. Arbusto escandente, face abaxial dos folíolos serícea ..... 7. M. floribundum var. floribundum

9'. Arvoreta, face abaxial dos folíolos puberulenta ou glabrescente.

10. Folíolos elípticos ou largo-elípticos, de ápice arredondado ou obtuso, cálice campanulado 15. M. quinatum var. parviflorum

10'. Folíolos lanceolados ou oblongo-lanceolados, de ápice acuminado ou agudo, cálice cilíndrico 16. M. quinatum var. quinatum

8'. Estípulas modificadas em espinhos.

11. Espinhos retilíneos na base da folha.

12. Folíolos oblongos ou estreito-oblongos, de ápice retuso, cálice campanulado

8. M. hirtum

12'. Folíolos elípticos ou estreito-elípticos, de ápice agudo, cálice cilíndrico

14. M. pilosum

11'. Espinhos recurvados na base da folha.

13. Folíolos sésseis

12. M. multifoliolatum

13'. Folíolos subsésseis ou peciolados.

14. Pecíolo e raque com dois tipos de revestimento (esparso-setosos e vilosos), folíolos oblongos ou estreito-oblongos. 10. M. isadelphum

14'. Pecíolo e raque com apenas um tipo de revestimento, folíolos elípticos, estreitoelípticos ou largo-elípticos.

15. Árvore, sâmaras falciformes.

16. Espinhos mais que $2 \mathrm{~mm}$ compr., folíolos de ápice emarginado ou retuso, cálice externamente seríceo, região seminífera castanho-escura, estrigosa e tomentosa 4. M. biovulatum

16'. Espinhos até $2 \mathrm{~mm}$ compr., folíolos de ápice agudo ou apiculado, cálice externamente glabrescente, região seminífera acinzentada, tomentosa a puberulenta

6. M. eriocarpum

15'. Arbusto escandente ou liana, sâmaras cultriformes.

17. Ramos vilosos, folhas 29-39 folioladas, cálice campanulado, flores com asa oblonga 1. M. aculeatum

17'. Ramos glabros, folhas 9-17 folioladas, cálice cilíndrico, flores com asa elíptica ou estreito-elíptica. 3. M. amplum

1. Machaerium aculeatum Raddi, Mem. Mat. Fis. Soc. Ital. Sci. Modena, Pt. Mem. Fis. 18(2): 398. 1820.

Arbustos escandentes, 2,5-4 m alt., às vezes lianas; ramos vilosos; espinhos recurvados, ca. 6 mm compr.; lenticelas inconspícuas, exsudado acastanhado. Folhas 29-39-folioladas; pecíolo, raque e peciólulo vilosos a glabrescentes, pecíolo 1-2 cm compr., raque 10,5-16,5 cm compr., peciólulo 1-1,5 mm compr.; folíolos peciolados, alternos, discolores, seríceos a glabrescentes, elípticos ou estreito-elípticos, base arredondada, às vezes equilateral, ápice emarginado ou retuso, nervação craspedódroma, 2-3,5 × 0,5-1 cm. Panículas terminais, axilares, eixos vilosos, o principal ca. 16 $\mathrm{cm}$ compr. Flores subsésseis, pedicelos vilosos, ca. $1 \mathrm{~mm}$ compr.; bractéolas internamente glabras, externamente esparso-tomentosas a glabras, elípticas ou largo-ovadas, 2,5-3,5×2,5-3 mm; cálice campanulado, glabro, lacínios superiores oblongos, os inferiores estreito-oblongos, ca. $6 \mathrm{~mm}$ compr.; corola lilás ou rosa; estandarte ventralmente glabro, com mácula amarela, dorsalmente seríceo, largo- 
ovado, ápice obcordado, às vezes retuso, ca. $8 \times 5$ $\mathrm{mm}$; asa e pétalas da quilha glabras, oblongas, asa 8 $9 \times 5-6 \mathrm{~mm}$, pétalas da quilha 7-7,5 $\times 4-5 \mathrm{~mm}$; androceu monadelfo, filetes de mesma altura, anteras elípticas; ovário velutino, estigma capitado. Sâmaras cultriformes, estipe tomentoso, ca. $2 \mathrm{~mm}$ compr., região seminífera glabra, castanho-escura, 1-2 $2 \times 0,5-1 \mathrm{~cm}$, asa glabra, oblonga, castanho-clara, pontuações enegrecidas dispersas, $1,5-4,5 \times 1-1,5 \mathrm{~cm}$.

Material selecionado: MATO GROSSO DO SUL: Corumbá, 9.IX.2004, fl., R.R. Silva \& R. Silva 1120 (CGMS, UEC); 26.XI.2004, fr., R.R. Silva \& R. Silva 1329 (CGMS, UEC). Ladário, 18.X.2001, fr., G.A. Damasceno Junior et al. 2816 (CGMS, COR). Miranda, 1.VIII.1996, fl., M. Nadruz et al. 1259 (RB).

Machaerium aculeatum caracteriza-se pelos espinhos recurvados, folíolos elípticos ou estreitoelípticos, de ápice emarginado ou retuso, asa e pétalas da quilha oblongas e filetes com duas falanges pentâmeras. Estudos realizados no Rio de Janeiro (Lima 1995) e em Minas Gerais (MendonçaFilho 1996) relatam a espécie como liana, porém seu hábito parece variar de arbustivo escandente (Silva 1120,1329 ) a lianescente (Damasceno-Júnior 2816). Os espinhos recurvados a diferenciam de M. hirtum e de M. pilosum, que possuem espinhos retilíneos. Também pode ser distinguidas de $M$. hirtum a partir de dados citotaxonômicos (Mendonça-Filho et al. 2007) e de M. isadelphum pelos folíolos, que são oblongos ou estreitooblongos naquela espécie. É restrita ao noroeste de Mato Grosso do Sul, podendo ser encontrada em floresta estacional semidecidual, Savana (Cerrado) e Savana florestada (Cerradão). Floresce nos meses de agosto e setembro, frutificando em outubro e novembro.

2.Machaerium acutifolium Vogel, Linnaea 11: 187. 1837.

Arvoretas a árvores, 2,5-18 m alt.; ramos glabros, às vezes esparso-seríceos; estípulas não modificadas em espinhos; lenticelas esbranquiçadas, exsudado acastanhado. Folhas 917-folioladas; pecíolo e raque pubescentes a glabros, pecíolo $2-5,5 \mathrm{~cm}$ compr., raque $6-19,5 \mathrm{~cm}$ compr., peciólulo viloso a glabrescente, $2-6 \mathrm{~mm}$ compr.; folíolos peciolados, alternos ou subopostos, concolores, glabros, tomentosos a esparso-tomentosos sobre a nervura principal da face abaxial, lanceolados ou oblongo-lanceolados, raramente oval-lanceolados, base arredondada ou atenuada, às vezes oblíqua, ápice agudo, raramente acuminado, nervação broquidódroma, 4-8 × 1,5-3 $\mathrm{cm}$. Panículas terminais, axilares, eixos glabrescentes a glabros, o principal 3,5-9,5 cm compr. Flores sésseis ou subsésseis, pedicelos vilosos, ca. $1 \mathrm{~mm}$ compr.; bractéolas internamente glabras, externamente tomentosas, ovadascomprimidas, $0,5-1,5 \times 1,5-2 \mathrm{~mm}$; cálice campanulado, internamente glabro, externamente glabrescente, ápice tomentoso, lacínios superiores elípticos, inferiores estreito-elípticos, 1-3 mm compr.; corola alva ou creme; estandarte ventralmente glabro, dorsalmente denso-seríceo, obovado, raramente ovado, ápice obtuso ou retuso, $5,5-7 \times 2,5-6 \mathrm{~mm}$; asa e pétalas da quilha glabras, estreito-oblongas, asa 4,5-7,5 $\times 1,5-2,5 \mathrm{~mm}$, pétalas da quilha $6-7 \times 1,5-3 \mathrm{~mm}$, tomentosas na região da unguícula; androceu monadelfo, filetes de alturas diferentes, anteras oblongas ou triangulares; ovário velutino, estigma capitado. Sâmaras tenuemente falciformes; estipe tomentoso a glabrescente, 5-11 mm compr., região seminífera esparso-pubescente a glabra, marrom, 3,5-4,5 $\times 1-2 \mathrm{~cm}$, asa glabrescente, elíptica, castanho-clara, discolor na região seminífera, com pontuações brilhantes dispersas, $3,5-6 \times 1-2,5 \mathrm{~cm}$.

Material selecionado: MATO GROSSO: Alto Paraguai, 20.V.1997, fr., V.C. Souza et al. 16687 (CGMS, ESA). Aripuanã, 3.VII.1997, fr., G.F. Árbocz et al. 4071 (CGMS, ESA). Barra do Garças, 22.VIII.1972, fl., J.A. Ratter et al. s/n (UB 4552). Chapada dos Guimarães, 23.II.1997, fr., A.G. Nave et al. 1193 (CGMS, ESA). Cuiabá, 1.XI.1914, fl., J.G. Kuhlmann 426 (RB); 3.II.1979, fl., M.G. Silva \& A. Pinheiro 4423 (INPA, RB). Diamantino, 15.V.1997, fr., V.C. Souza et al. 16185 (CGMS, ESA). Guarantã do Norte, 8.X.1993, fr., V.C. Souza et al. 16185 (CH). Nova Xavantina, 28.III.1997, fr., G.F. Árbocz et al. 3690 (CGMS, ESA). Ponte Branca, 20.I.1988, fr., J. Ramos et al. 362 (INPA, RB). Pontes e Lacerda, 9.XI.1996, fl., G. Hatschbach et al. 65479 (RB); 14.IV.1997, fr., G.F. Árbocz 3777 (ESA). Rosário Oeste, 9.X.1997, fl., V.C. Souza et al. 20505 (CGMS, ESA). MATO GROSSO DO SUL: Aquidauana, 15.XII.1999, fl., M.S. Ferrucci 1472 (ESA). Bataguaçu, 24.XI.1992, fl., I. Cordeiro et al. 1196 (SP). Bela Vista, 11.II.1993, fr., G. Hatschbach et al. 58886 (SPSF). Bonito, 8.XI.2002, fl., A. Pott et al. 10500 (HMS). Campo Grande, 19.VIII.2004, fl., A. Pott \& V.J. Pott 7065 (HMS). Corumbá, 16.IX.1987, fr., A. Pott et al. 3430 (CPAP, HMS). Coxim, 23.II.1994, fr., A. Pott \& V.J. Pott 6616 (CPAP, CGMS). Dourados, 19.X.1999, bot., A. Sciamarelli \& Z.V. Pereira 770 (DDMS). Miranda, 1.VI.2006, fl., C.R. Lehn et al. s/n (CGMS 17591). Nioaque, 20.X.1988, fl., G. Hatschbach et al. 52427 (ESA, INPA, MBM). Nova Andradina, 24.X.1986, fl., $U$. Pastore \& R.M. Klein 132 (RB). Piraputanga, 16.VI.2002, fr., A.L.B. Sartori et al. 921 (CGMS, DDMS). Selvíria, 
19.XII.1984, fr., M.R. Pereira-Noronha 478 (RB); 6.XI.1985, fl., A.M.A. Tozzi et al. s/n (HRCB 9931, SP 224627, UB 139). Sidrolândia, 12.IX.2001, fl., $A$. Sciamarelli et al. 998 (CGMS). Terenos, 30.III.1996, fr., A. Pott \& S.G. Nunes 7734 (CPAP, HMS). Três Lagoas, 30.XII.2004, fr., E.L. Jacques et al. 1658 (CEUL, CGMS).

Material adicional selecionado: MINAS GERAIS: São João Batista, 1837, fl., J.E. Pohl s/n. (foto K).

Machaerium acutifolium é reconhecida pelos folíolos lanceolados ou oblongo-lanceolados, caule com sulcos longitudinais e cicatrizes horizontais (Sartori \& Tozzi 1998), estandarte denso-seríceo na face dorsal e sâmaras tenuemente falciformes. Pode ser confundida com $M$. brasiliense e $M$. villosum devido à forma e dimensão dos folíolos. Entretanto, M. acutifolium possui pecíolo e raque pubescentes a glabros, enquanto em $M$. brasiliense eles são vilosos a esparso-vilosos, e seus folíolos são glabros, enquanto em M. villosum eles são velutinos a esparso-velutinos. Neste estudo, a variação morfológica não permitiu o reconhecimento de táxons infraespecíficos, pautados na morfologia dos folíolos e no comprimento das flores. A espécie está amplamente distribuída em Mato Grosso e Mato Grosso do Sul, principalmente em Savana (Cerrado) e Savana Florestada (Cerradão), mas também ocorre em Florestas Estacionais Decidual e Semidecidual e Floresta Ombrófila Densa. Floresce e frutifica simultaneamente, o ano todo.

3. Machaerium amplum Benth., Comm. Legum. Gen.: 33. 1837.

Arbustos escandentes, 2-4 m alt.; ramos glabros; espinhos recurvados, 2-6 mm compr.; lenticelas esbranquiçadas, exsudado amarelado. Folhas 9-17-folioladas; pecíolo, raque e peciólulo pubescentes a glabrescente, pecíolo $1-2,5 \mathrm{~cm}$ compr., raque 3-9,5 cm compr., peciólulo $1-3 \mathrm{~cm}$ compr.; folíolos peciolados, alternos, discolores, glabros, seríceos a esparso-seríceos sobre a nervura principal da face abaxial, elípticos, oblongo-elípticos ou largo-elípticos, base arredondada, ápice retuso, às vezes apiculado, nervação craspedódroma, 2$3,5 \times 0,5-2 \mathrm{~cm}$. Panículas terminais, axilares, eixos tomentosos, o principal 5,5-15,5 cm compr. Flores pediceladas, pedicelos tomentosos, 1-2,5 $\mathrm{mm}$ compr.; bractéolas glabras, largo-elípticas ou largoovadas, 1,5-3 × 1,5-2,5 mm; cálice cilíndrico, esparso-tomentoso a glabro, lacínios superiores oblongos, inferiores estreito-oblongos, 4-5 mm compr.; corola azul, lilás ou roxa; estandarte ventralmente glabro, com mácula alva ou creme, dorsalmente seríceo, obovado ou ovado, ápice obtuso ou retuso, $8-13 \times 6,5-7,5 \mathrm{~mm}$; asa e pétalas da quilha glabras, asa elíptica ou estreito-elíptica, aurícula breve, 8,5-13 × 3,5-4,5 mm, pétalas da quilha oblongas, $11-13 \times 3,5-5 \mathrm{~mm}$; androceu monadelfo, filetes de mesma altura, anteras elípticas; ovário esparso-velutino, estigma clavado. Sâmaras cultriformes, estipe velutino, 6-9 mm compr., região seminífera tomentosa a glabra, castanho-escura; 1-2,5 $\times 0,5-1 \mathrm{~cm}$, asa tomentosa a glabra, oblonga, castanhoclara, discolor na região seminífera, 2-3,5×0,5-1,5 cm. Material selecionado: MATO GROSSO: Alta Floresta, 29.VI.1988, fl., M. Macedo \& A. Assumpção 63 (BHCB, INPA); 15.III.1989, fr., M. Macedo \& A. Assumpção $s / n$ (INPA 176628). Barra do Garças, 21.IV.1978, fl., G.J. Shepherd et al. 7511 (RB). Cuiabá, 22.VII.1976, fr., A.A. Maciel et al. 179 (INPA). Gaúcha do Norte, 29.III.1979, fl., F. Dario et al. 1149 (CGMS, ESA). Jauru, 24.IV.1997, fl., G.F. Árbocz 3811 (CGMS, ESA). Nortelândia, 21.V.1997, fr., V.C. Souza et al. 16752 (ESA). Nova Ubiratã, 28.IV.1997, fl., A.G. Nave et al. 1333 (CGMS, ESA). Nova Xavantina, 2.V.1968, fl., R.R. Santos et al. $s / n$ (RB 165758, UB 4742). Pontes e Lacerda, 4.V.1983, fl., L. Carreira et al. 670 (INPA). Ribeirão Cascalheira, 18.VIII.1998, fr., J.A. Ratter et al. s/n (CH 23619, UB 8089). Rio Branco, 11.V.1995, fl., G. Hatschbach et al. 62635 (MBM, RB). MATO GROSSO DO SUL: Anastácio, 20.X.1988, fl., G. Hatschbach et al. 52446 (INPA). Aquidauana, 15.V.1989, fl., A. Pott \& C.A. Mazza 4773 (CPAP, HMS). Campo Grande, 19.IX.2006, fl. e fr., C.A. Polido 42 (CGMS). Corumbá, 25.VI.1985, fl. e fr., A. Pott \& V.J. Pott 1942 (CPAP, HMS). Coxim, 1.V.1911, fl., F.C. Hoehne 2550 (RB, SP). Dourados, 4.VIII.2001, fr., A. Sciamarelli et al. 919 (CGMS, DDMS). Miranda, 17.VIII.1990, fr., U.M. Resende 163 (CGMS). Nioaque, 2.V.1995, fl., G. Hatschbach et al. 62210 (BHCB, MBM).

Material adicional selecionado: GOIÁS: Caretão, 1837, fl., J.E. Pohl s/n. (foto UEC).

Machaerium amplum caracteriza-se pelo hábito escandente, espinhos recurvados e folíolos elípticos ou oblongo-elípticos, com nervação craspedódroma, corola azul, lilás ou roxa, com mácula alva ou creme e ovário esparso-velutino. Apesar da semelhança nos folíolos, M. amplum diferencia-se de $M$. biovulatum pelo hábito escandente e pelos folíolos menores, com até 3,5 cm compr. Está amplamente representada nos dois Estados, exceto na Região Leste de Mato Grosso do Sul. Ocorre principalmente em Savana (Cerrado) e Savana Florestada, podendo ser encontrada também em Floresta Estacional Decidual e Florestas Ombrófilas Aberta Submontana e Densa. Floresce de março a outubro e frutifica de maio a outubro. 
4. Machaerium biovulatum Micheli, Mém. Soc. Phys. Genève 34: 265; pl. 15. $1903 . \quad$ Fig. 1 a-j Árvores ca. $5 \mathrm{~m}$ alt.; ramos pubescentes; espinhos recurvados, ca. $6 \mathrm{~mm}$ compr.; lenticelas conspícuas, exsudado não observado. Folhas 1731-folioladas; pecíolo e raque tomentosos a glabrescentes, pecíolo 1,5-4,5 cm compr., raque 12,5-21 cm compr., peciólulo viloso a glabrescente, ca. $4 \mathrm{~mm}$ compr.; folíolos peciolados, alternos, discolores, glabrescentes, seríceos sobre nervura principal da face abaxial, elípticos, oblongo-elípticos ou largo-elípticos, os apicais obovados, base oblíqua, ápice emarginado ou retuso, nervação craspedódroma, 4-6×1-2,5 cm. Panículas terminais, axilares, eixos velutinos, o principal ca. $26 \mathrm{~cm}$ compr. Flores pediceladas, pedicelos velutinos, 2-4 mm compr.; bractéolas internamente glabras, externamente tomentosas a esparso-tomentosas, largo-ovadas, ca. $3 \times 2,5-3 \mathrm{~mm}$; cálice campanulado, internamente glabro, externamente seríceo, lacínios superiores oblongos, inferiores estreito-oblongos, ca. 4,5 mm compr.; corola lilás; estandarte ventralmente glabro, dorsalmente esparso-seríceo, largo-elíptico, ápice retuso, ca. 12,5 ×8,5 mm; asa e pétalas da quilha glabras, asa $12-13 \times 3,5-5 \mathrm{~mm}$, elíptica, pétalas da quilha $9,5-10,5 \times 7-8 \mathrm{~mm}$, oblongas; androceu monadelfo, filetes de mesma altura, anteras oblongas; ovário velutino, estigma clavado. Sâmaras falciformes, estipe velutino, 7-9 mm compr., região seminífera estrigosa e tomentosa, castanho-escura, 1-2 × 0,5-1 cm, asa estrigosa e tomentosa, oblonga, castanho-clara, $3-4 \times 1-1,5 \mathrm{~cm}$. Material selecionado: MATO GROSSO: Figueirópolis d'Oeste, 8.V.1995, fl., G. Hatschbach et al. 62489 (ESA, MBM). Indiavaí, 8.V.1995, fr., G. Hatschbach et al. 62497 (MBM, RB).

Machaerium biovulatum apresenta como características diagnósticas o hábito arbóreo, eixo da inflorescência e pedicelo velutinos, região seminífera estrigosa e tomentosa. Esta amplamente distribuída na América Central, Venezuela e Brasil (Lozano \& Klitgaard 2006). Foi encontrada na região sudoeste de Mato Grosso, sendo sua ocorrência inédita para o Estado. Habita exclusivamente Floresta Ombrófila Densa. Floresce e frutifica em maio.

\section{Machaerium brasiliense Vogel, Linnaea 11: 185. 1837. \\ Fig. $1 \mathrm{k}-1$}

Árvores até $23 \mathrm{~m}$ alt.; ramos tomentosos a glabrescentes; estípulas não modificadas em espinhos; lenticelas amareladas, exsudado amarronzado. Folhas 7-9-folioladas; pecíolo, raque e peciólulo vilosos a esparso-vilosos, pecíolo 3,5$5 \mathrm{~cm}$ compr., raque $6,5-10,5 \mathrm{~cm}$ compr., peciólulo 5-7 mm compr.; folíolos peciolados, alternos ou subopostos, concolores, glabros, vilosos sobre a nervura principal da face abaxial, oblongo-elípticos ou oblongo-lanceolados, base equilateral, ápice acuminado, nervação broquidódroma, 6,5-9,5×2$3 \mathrm{~cm}$. Racemos simples, axilares, eixos ferrugíneovilosos. Flores pediceladas, pedicelos ferrugíneovilosos, ca. $1 \mathrm{~mm}$ compr.; bractéolas ferrugíneovilosas, linear, ca. $2 \mathrm{~mm}$ compr.; cálice campanulado, ferrugíneo-tomentoso externamente, ca. $3 \mathrm{~mm}$ compr.; corola creme-esverdeada; estandarte dorsalmente seríceo na metade superior, orbicular, $6-7 \times$ ca. $5 \mathrm{~mm}$; asa e pétalas da quilha $7-8 \times$ ca. 3 $\mathrm{mm}$, oblongas, seríceas na unguícula da asa e no dorso das pétalas da quilha; androceu diadelfo, filetes de alturas diferentes, anteras oblongas a elípticas; ovário esparsamente ferrugíneo-vilosos (Sartori \& Tozzi, 1998). Sâmaras tenuemente falciformes, estipe glabro, ca. $1 \mathrm{~mm}$ compr., região seminífera esparso-pubescente a glabra, marrom, 2-3×1-2 cm, asa glabrescente, elíptica, castanhoescura, manchas claras próximas da região seminífera, 4,5-6×1,5-cm.

Material selecionado: MATO GROSSO: Chapada dos Guimarães, 6.X.1984, fr., J.R. Borges et al. 137 (INPA, UB). Jauru, 6.VI.1995, S.M. Salis et al. 908 (CPAP). Pontes e Lacerda, 15.IX.1997, fr., A.G. Nave et al. 2172 (CGMS, ESA).

Machaerium brasiliense é reconhecida pelo revestimento viloso a esparso-viloso no pecíolo, raque e face abaxial dos folíolos, além da sâmara tenuemente falciforme. Ocorre nas regiões centrosul e sudoeste de Mato Grosso; ocorre em Floresta Estacional Semidecidual e Savana Florestada (Cerradão). Floração não observada; frutificação em setembro e outubro.

6. Machaerium eriocarpum Benth., Comm. Legum. Gen.: 34. 1837.

Árvores 2-8 m alt.; ramos pubescentes a glabrescentes; espinhos recurvados, ca. $2 \mathrm{~mm}$ compr.; lenticelas inconspícuas, exsudado amarronzado. Folhas 43-63-folioladas; pecíolo e raque velutinos a glabrescentes, pecíolo 4-7 mm compr., raque 3,5-9,5 cm compr., peciólulo viloso a esparso-viloso, ca. $1 \mathrm{~mm}$ compr.; folíolos subsésseis, alternos, raramente subopostos, discolores, glabros na face adaxial, glabrescentes na abaxial, tomentosos a glabrescentes sobre a nervura principal e a margem, estreito-elípticos, base arredondada ou 

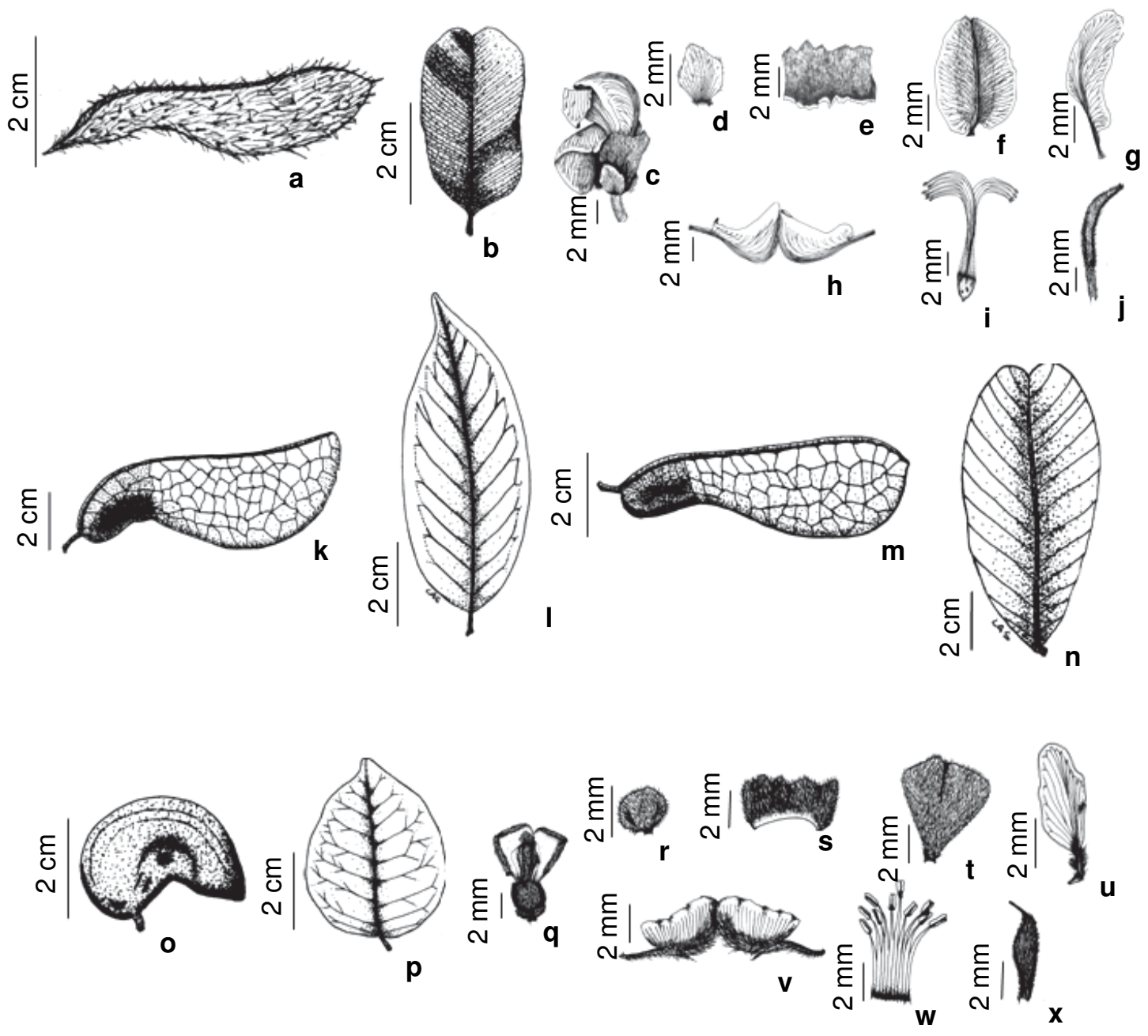

Figura 1 - a-j. Machaerium biovulatum (a-b Hatschbach 62497; c-j Hatschbach 62489) - a. fruto; b. folíolo, face adaxial; c. flor; d. bractéola; e. cálice; f. estandarte; g. asa; h. pétalas da quilha; i. androceu; j. gineceu. k-1. $M$. brasiliense (Nave 2172) - k. fruto; 1. folíolo, face adaxial. m-n. M. floribundum var. floribundum (Árbocz 3472) - m. fruto; n. folíolo, face adaxial. o-w. M. inundatum (o-p Mattos 15535; q-w Árbocz 4612) - o. fruto; p. folíolo, face adaxial; q. flor; r. bractéola; s. cálice; t. estandarte; u. asa; v. pétalas da quilha; w. androceu; x. gineceu.

Figure 1 - a-j. Machaerium biovulatum (a-b Hatschbach 62497; c-j Hatschbach 62489) - a. fruit; b. leaflet, adaxial surface; c. flower d. bracteole; e. calyx; f. standard; g. wing; h. petals of the keel; i. androecium; j. gynoecium. k-1. M. brasiliense (Nave 2172) - k. fruit; 1. leaflet, adaxial surface. m-n. M. floribundum var. floribundum (Árbocz 3472) - m. fruit; n. leaflet, adaxial surface. o-w. M. inundatum (o-p Mattos 15535, q-w Árbocz 4612) - o. fruit; p. leaflet, adaxial surface; q. flower; r. bracteole; s. calyx; t. standard; u. wing; v. petals of the keel; w. androecium; $x$. gynoecium. 
oblíqua, ápice agudo ou apiculado, nervação craspedódroma, $0,5-1,5 \times$ até $0,5 \mathrm{~cm}$. Panículas terminais, axilares, eixos velutinos, o principal 7,5-19 cm compr. Flores subsésseis, pedicelos velutinos, ca. $1 \mathrm{~mm}$ compr.; bractéolas glabras, às vezes externamente esparso-tomentosas, largo-ovadas ou ovado-comprimidas, 1,5-2,5 x 1-2,5 mm, cálice campanulado, internamente glabro, externamente glabrescente, densotomentoso sobre o ápice, lacínios superiores elípticos, os estreito-elípticos, 4-5 mm compr., corola azulada, lilás ou roxa; estandarte glabrescente, com mácula creme, elíptico ou largoobovado, ápice obcordado ou retuso, 7-9,5 × 7,5$9,5 \mathrm{~mm}$, asa e pétalas da quilha glabras, asa obovada, 7-10 × 4-6,5 mm, pétalas da quilha oblongas, 6,5-8,5 ×4-6 mm; androceu monadelfo, filetes de mesma altura, anteras oblongas; ovário esparso-velutino, estigma clavado. Sâmaras falciformes; estipe tomentoso, 6-9 $\mathrm{mm}$ compr., região seminífera tomentosa a puberulenta, acinzentada, $1-2,5 \times 0,5-1,5 \mathrm{~cm}$, asa tomentosa a puberulenta, elíptica, acinzentada, $2,5-4,5 \times 0,5-1,5 \mathrm{~cm}$. Material selecionado: MATO GROSSO: Cuiabá, 20.X.1990, fl., D.N. Conceição s/ $n$ (RB 295194). Poconé, 30.XI.1982, fr., J.U. Santos \& C.S. Rosário 611 (INPA.). MATO GROSSO DO SUL: Bela Vista, 13.XI.1977, fl., J.S. Costa 148 (RB); 21.IV.1984, fr., J.F.M. Valls et al. 7649 (RB). Bonito, 11.IX.1996, fl., J.A. Ratter et al. s/n (UB 7670). Corumbá, 14.XII.1986, fl. e fr., C.N. Cunha et al. 2113 (CPAP, HMS). Ladário, 16.XI.1996, fl., M.A.O. Bezerra \& J.L. Peixoto 7 (CGMS, COR). Miranda, 18.XII.1990, fl., U.M. Resende et al. 360 (CGMS); 19.XI.2002, fr., A. Pott et al. 10860 (HMS). Porto Murtinho, 5.IV.2001, fr., A.L.B. Sartori et al. 475 (CGMS, HMS); 16.IV.2005, fl., L.E.A.M. Lescano et al. 209 (CGMS).

Machaerium eriocarpum possui como características diagnósticas os folíolos estreitoelípticos, com ápice agudo ou apiculado, de margem espessada, ápice do cálice densotomentoso e sâmaras falciformes, acinzentadas, de asa elíptica. Considerando-se o tamanho dos folíolos, é próxima de $M$. pilosum, da qual se diferencia principalmente pelo hábito arbóreo (versus escandente em $M$. pilosum). As inflorescências axilares, paniculadas a aproximam de $M$. hirtum, da qual se distingue pelos folíolos estreito-elípticos, de ápice agudo ou apiculado e sâmaras falciformes ( $v s$. folíolos oblongos ou estreito-oblongos, de ápice retuso, e sâmaras cultriformes). Ocorre na região oeste de Mato Grosso do Sul e no sudoeste de Mato
Grosso. Sua ocorrência é inédita para o Mato Grosso do Sul. Os ambientes preferenciais são Florestas Estacionais Decidual e Semidecidual, Savana (Cerrado), Savana Florestada (Cerradão), Savana Parque e Floresta-Estépica Florestada (Chaco), este último exclusivo de Mato Grosso do Sul. Floresce de fevereiro a dezembro e frutifica de março a dezembro.

7. Machaerium floribundum Benth. var. floribundum, J. Proc. Linn. Soc., Bot. 4(Suppl.): 68. 1860.

Fig. $1 \mathrm{~m}-\mathrm{n}$

Arbustos escandentes; ramos puberulentos; estípulas não modificadas em espinhos; lenticelas enegrecidas, exsudado amarronzado. Folhas 5-9folioladas; pecíolo e raque tomentosos a glabrescentes, pecíolo 3-5 cm compr., raque 6-10,5 cm compr., peciólulo tomentoso, 3-5 mm compr.; folíolos peciolados, alternos, discolores, glabrescentes a glabros na face adaxial, seríceos na abaxial, obovados, base equilateral ou oblíqua, ápice retuso, nervação craspedódroma, 6,5-11,5× 4-6 cm. Panículas terminais, axilares, eixos puberulentos a tomentosos, o principal $15-34 \mathrm{~cm}$ compr. Flores sésseis; bractéolas tomentosas, deltoides, ca. $2 \times 2 \mathrm{~mm}$; cálice campanulado, tomentoso, ca. $3 \mathrm{~mm}$ compr.; corola alva a esverdeada; estandarte dorsalmente tomentoso, ca. $10 \times 4 \mathrm{~mm}$; asa ca. $9 \times 4 \mathrm{~mm}$, pétalas da quilha ca. 7 $\times 3,5 \mathrm{~mm}$; androceu monadelfo, filetes de mesma altura; estigma reto (Lozano \& Klitgaard, 2006). Sâmaras imaturas, cultriformes, estipe velutino, ca. $1 \mathrm{~mm}$ compr., região seminífera serícea, castanhoclara, 1,5-2 $\times 0,5-1,5 \mathrm{~cm}$, as a glabrescente, oblonga, amarelada, 3,5-5×1,5-2 cm.

Material selecionado: MATO GROSSO: Cláudia, 9.XI.1996, fr., G.F. Arbócz et al. 3472 (CGMS, ESA).

Machaerium floribundum var. floribundum possui hábito escandente, folíolos obovados e sâmara com região seminífera serícea. O material analisado possui flores de $9-10 \mathrm{~mm}$ compr. e cálice de ca. $3 \mathrm{~mm}$ compr., se enquadrando na circunscrição da variedade típica (flor de 6-10 mm compr. e cálice de 3-4 mm compr.; Rudd, 1987). As var. parviflorum Benth. e var. hypergyreum (Harms) Rudd podem apresentar flores até 6(-7) mm compr. e cálice até 2,5 mm compr. (Rudd 1987). É registrada para a região norte de Mato Grosso, sendo este o primeiro registro no Estado. É encontrada em Floresta Ombrófila Aberta. O período de floração não foi observado, mas apresentou frutos imaturos em novembro. 
8. Machaerium hirtum (Vell.) Stellfeld, Tribuna Farm. 12: 132. 1944.

Árvores 3-11 m alt.; ramos pubescentes a glabrescentes; espinhos retilíneos, 1,5-3 mm compr.; lenticelas inconspícuas, exsudado amarelado. Folhas 31-47-folioladas; pecíolo e raque vilosos a glabrescentes, pecíolo 3-10 mm compr., raque 6-12,5 cm compr., peciólulo glabrescente, 1 $2 \mathrm{~mm}$ compr.; folíolos subsésseis, alternos ou subopostos, discolores, glabros na face adaxial, esparso-seríceos a glabros na abaxial, oblongos ou estreito-oblongos, os apicais oblongo-lanceolados, base oblíqua, raramente arredondada, ápice retuso, nervação craspedódroma, $1-2 \times$ até $0,5 \mathrm{~cm}$. Panículas terminais, axilares, eixos vilosos, o principal 9,5-16,5 cm compr. Flores subsésseis, pedicelos vilosos, ca. $1 \mathrm{~mm}$ compr., bractéolas glabras, tomentosas sobre margem da face externa, largo-ovadas ou ovadas, $2-2,5 \times 1,5-2,5 \mathrm{~mm}$; cálice campanulado, internamente glabrescente, externamente esparso-seríceo, lacínios superiores oblongos, os inferiores estreito-oblongos, 3,5-5,5 mm compr.; corola lilás; estandarte ventralmente glabro, com mácula alva, dorsalmente seríceo a esparso-seríceo, obovado, raramente ovado, ápice emarginado, 6,5-11 ×5,5-8 $\mathrm{mm}$; asa e pétalas da quilha glabras, asa elíptica, 7,5-12 $\times 3-5,5 \mathrm{~mm}$, pétalas da quilha oblongas, 7-10 × 4,5-7,5 mm; androceu monadelfo, filetes de mesma altura, anteras elípticas; ovário velutino, estigma clavado. Sâmaras cultriformes, estipe tomentoso, 5,5-7,5 mm compr., região seminífera tomentosa a glabra, castanho-escura, $1-2 \times 0,5-1 \mathrm{~cm}$, asa tomentosa a glabra, oblonga ou ovada, castanhoclara, 2-3,5 × 1-1,5 cm.

Material selecionado: MATO GROSSO: Chapada dos Guimarães, 21.II.1997, fl., A.G. Nave et al. s/n (CGMS 17581, ESA). MATO GROSSO DO SUL: Anaurilândia, 19.VI.1998, fr., J.L.G. Salvador et al.50 (CGMS). Bataguaçu, 22.I.1992, fl., M.M. Los s/n (CGMS 17590). Bela Vista, 2.XI.1998, fl., O.S. Ribas et al. 2450 (ESA, INPA, SO). Bodoquena, 23.V.2002, fr., S. Aragaki \& U.M. Resende 985 (DDMS). Bonito, 12.VIII.2001, fr., R. Constantino 130 (CGMS, HRCB); 15.XI.2002, fl., A. Pott et al. 10744 (HMS). Camapuã, 26.II.2002, fl., A. Pott et al. 9523 (HMS). Caarapó, 2.II.2001, fl., A. Sciamarelli et al. 846 (DDMS). Corumbá, 31.III.2004, fl. e fr., R.R. Silva \& J.S. Velásquez 623 (CGMS, UEC). Ladário, 16.III.2003, fl., G.A. Damasceno Junior et al. 2763 (CGMS, COR). Miranda, 19.II.1993, fl., A. Pott et al. 7095 (CPAP). Mundo Novo, 7.II.1993, fl., G. Hatschbach et al. 58552 (MBM, SPSF). Piraputanga, 6.VIII.2006, fr., C.A. Polido et al. 3 (CGMS 17579). Rio
Brilhante, 24.X.2002, fl., A. Sciamarelli et al. 1344 (CGMS, DDMS). Rio Negro, 14.IV.1984, fl. e fr., V.J. Pott et al. 3508 (CGMS). Três Lagoas, 22.VI.1996, fr., J.C. Gomes Junior 1988 (CPAP, HMS, SP, UB).

Material selecionado: BRASIL. Brasília meridionalis, 1836, fl., Humboldt 240 (foto UEC).

Machaerium hirtum é reconhecida pela casca lisa, com cicatrizes circulares (Sartori \& Tozzi 1998), espinhos retilíneos, folíolos oblongos ou estreitooblongos, de nervação craspedódroma, eixo da inflorescência e pedicelo vilosos e hábito arbóreo. Assemelha-se a $M$. isadelphum por causa dos folíolos oblongos ou estreito-oblongos, porém eles são menores em $M$. hirtum (mais que $2 \mathrm{~cm}$ compr. em $M$. isadelphum) e os espinhos são recurvados em $M$. isadelphum. Difere de $M$. aculeatum e $M$. pilosum pelo hábito ereto ( $v s$. escandente naquelas espécies). As semelhanças em relação aos folíolos e às inflorescências também podem levar a identificações equivocadas entre $M$. hirtum e $M$. eriocarpum. No entanto, essas duas espécies podem ser diferenciadas pelas sâmaras, cultriformes e castanho-escuras em M. hirtum, enquanto em $M$. eriocarpum elas são falciforme e acinzentada. Machaerium hirtum está amplamente distribuída em Mato Grosso do Sul, enquanto em Mato Grosso pode ocorrer nas regiões central e sudeste. Habita Florestas Estacionais Decidual e Semidecidual, Floresta Ombrófila Densa e Savana Florestada (Cerradão). Apresenta flores de agosto a abril e frutos de abril a agosto.

9. Machaerium inundatum (Mart. ex Benth.) Ducke, Arch. Jard. Bot. Rio de Janeiro 4: 311.1925.

Fig. $10-\mathrm{X}$

Árvores 2-5 m alt.; ramos glabrescentes, às vezes esparso-tomentosos; estípulas não modificadas em espinhos; lenticelas esbranquiçadas, exsudado amarronzado. Folhas 57-folioladas; pecíolo, raque e peciólulo esparsotomentosos a glabros, pecíolo 2-3,5 cm compr., raque $4-7 \mathrm{~cm}$ compr. e peciólulo 4-6 mm compr.; folíolos peciolados, alternos, concolores, glabros na face adaxial, esparso-seríceos sobre a nervura principal da face abaxial, ovados ou largo-ovados, base arredondada, ápice acuminado, nervação broquidódroma, 4-7 x 2-5 cm. Panículas axilares, eixos velutinos, o principal 2,5-5 cm compr. Flores sésseis; bractéolas internamente glabras, externamente velutinas, circulares ca. 1,5×2 mm; cálice cilíndrico, internamente glabro, externamente velutino, lacínios superiores largo- 
oblongos, os inferiores estreito-oblongos, 2,5-4 $\mathrm{mm}$ compr.; corola amarela na face interna, verdealvacenta na externa (Hoehne 1941); estandarte ventralmente glabro, dorsalmente velutino, obovado, ápice retuso, $6,5-8 \mathrm{~mm}$; asa e pétalas da quilha esparso-velutinas, asa estreito-elíptica, 7$8 \times 2-3 \mathrm{~mm}$; pétalas da quilha oblongas, $6-8 \times 2-$ $3,5 \mathrm{~mm}$; androceu monadelfo, filetes de alturas diferentes, anteras elípticas; ovário velutino, estigma capitado. Legumes samaroides, $2-3 \times 1,5-$ $2,5 \mathrm{~cm}$, sésseis, seríceos, amarelados.

Material selecionado: MATO GROSSO: Cocalinho, 1997, fl., G.F. Árbocz et al. 4612 (CGMS, ESA). Luciara, 15.VIII.1969, fr., J. Mattos 15535 (CGMS, SP); 25.XI.1977, fr., C.T. Falcão 5125 (RB).

Os folíolos ovados ou largo-ovados, de ápice acuminado, estandarte externamente velutino e fruto do tipo legume samaroide, seríceo são características diagnósticas de $M$. inundatum. Ocorre no extremo leste de Mato Grosso, exclusivamente em Floresta Ombrófila Densa. Seu período de floração não foi registrado, mas a frutificação ocorre de agosto a novembro.

10. Machaerium isadelphum (E. Mey.) Amshoff, Meded. Bot. Mus. Herb. Rijks Univ. Utrecht 52: 53. 1839.

Árvores, 4-12 m alt. ou arvoretas escandentes, ca. $2 \mathrm{~m}$ alt.; ramos vilosos a pubescentes, às vezes estrigosos; espinhos recurvados, 6-8 mm compr.; lenticelas esbranquiçadas, exsudado acastanhado. Folhas 25-49-folioladas; pecíolo e raque esparsosetosos e vilosos, pecíolo 0,5-2 cm compr, raque. 9,5$21 \mathrm{~cm}$ compr., peciólulo viloso a tomentoso, ca. $1 \mathrm{~mm}$ compr.; folíolos subsésseis, alternos na base da folha, opostos no ápice, discolores, seríceos a glabrescentes, pontuações enegrecidas na face adaxial, oblongos ou estreito-oblongos, base equilateral ou oblíqua, ápice emarginado ou retuso, nervação craspedódroma, 2,5-5 × 0,5-1,5 cm. Panículas terminais, axilares, eixos vilosos, o principal 6-7 cm compr. Flores pediceladas, pedicelos tomentosos, 2 $3 \mathrm{~mm}$ compr.; bractéolas internamente glabras, externamente esparso-tomentosas a glabras, ovadas ou largo-ovadas, 2,5-4×2-3 mm; cálice campanulado, internamente glabro, externamente esparso-viloso a glabro, lacínios superiores oblongos, inferiores estreito-oblongos, 5-6,5 mm compr.; corola roxa; estandarte ventralmente glabro, dorsalmente seríceo, ovado ou largo-ovado, ápice emarginado ou retuso, $7-9 \times 4,5-7 \mathrm{~mm}$; asa e pétalas da quilha glabras, asa elíptica, $9-10 \times 4-5 \mathrm{~mm}$, pétalas da quilha oblongas, $7,5-8,5 \times 4-5,5 \mathrm{~mm}$; androceu monadelfo, filetes de mesma altura, anteras oblongas; ovário velutino, estigma capitado. Sâmaras cultriformes, estipe tomentoso, 5,5-7 $\mathrm{mm}$ compr., região seminífera tomentosa a glabrescente, castanho-escura, 1-1,5× 0,5-1 cm, asa esparso-tomentosa a glabra, elíptica, castanho-clara, 2-3,5 ×1-1,5 cm.

Material selecionado: MATO GROSSO: Cáceres, 1.VIII.1908, fl., F.C. Hoehne 272 (RB). Poconé, 5.X.1989, fr., A. Pott 4990 (CPAP). MATO GROSSO DO SUL: Piraputanga, 24.IX.2006, fr., A.L.B. Sartori et al. s/n (CGMS 17586). Miranda, 1.VII.2006, fl. e fr., C.R. Lehn et al. s/n (CGMS 17592).

A espécie é caracterizada pelos espinhos recurvados e folíolos oblongos ou estreito-oblongos, de nervação craspedódroma, com pontuações enegrecidas na face adaxial. O hábito da espécie é variável, constando como árvore (Lehn s/n), arvoreta escandente (Pott 4990), arbustos ou lianas escandente (Lozano \& Klitgaard 2006). Sua ocorrência é inédita para Mato Grosso do Sul, onde se distribui nas regiões central e oeste. Em Mato Grosso, está restrita a região sudoeste. Em ambos os Estados, M. isadelphum ocorre em Floresta Estacional Semidecidual e Floresta Ombrófila Densa. Floresce e frutifica em julho e agosto, com frutificação se estendendo até outubro.

11. Machaerium macrophyllum Benth. var. macrophyllum, Comm. Legum. Gen.: 35. 1837.

Fig. $2 \mathrm{a}-\mathrm{j}$

Arbustos a árvores, 2-7 m alt.; ramos puberulentos a glabros; estípulas não modificadas em espinhos; lenticelas esbranquiçadas, exsudado amarronzado. Folhas 5-folioladas; pecíolo e raque esparso-tomentosos a glabrescentes, pecíolo $1-4,5 \mathrm{~cm}$ compr., raque 1,5-5,5 cm compr., peciólulo tomentoso a esparso-tomentoso, 2-5,5 mm compr.; folíolos peciolados, alternos ou subopostos, discolores, glabros, manchas vináceas na face adaxial, pubescentes sobre a nervura principal da face abaxial, oblongolanceolados, os apicais obovados, base arredondada ou equilateral, ápice agudo ou obtuso, nervação broquidódroma, 5-11,5×2-5,5 cm. Panículas terminais, axilares, eixos tomentosos, o principal 10,5-19 cm compr. Flores pediceladas, pedicelos vilosos, ca. $1 \mathrm{~mm}$ compr.; bractéolas internamente glabras, externamente tomentosas, ovadas, $1-2 \times 0,5-1 \mathrm{~mm}$; cálice campanulado, externamente viloso, internamente glabro, lacínios superiores largo-oblongos, os inferiores oblongos, 3-4 mm compr.; corola vinácea; estandarte glabro, largo-elíptico, ápice obtuso ou retuso, 7,5-8,5× 4-4,5 mm; asa e pétalas da quilha glabras, elípticas, asa ca. 7,5 × 2,5 mm, pétalas da quilha $6-7 \times 2-3 \mathrm{~mm}$; 

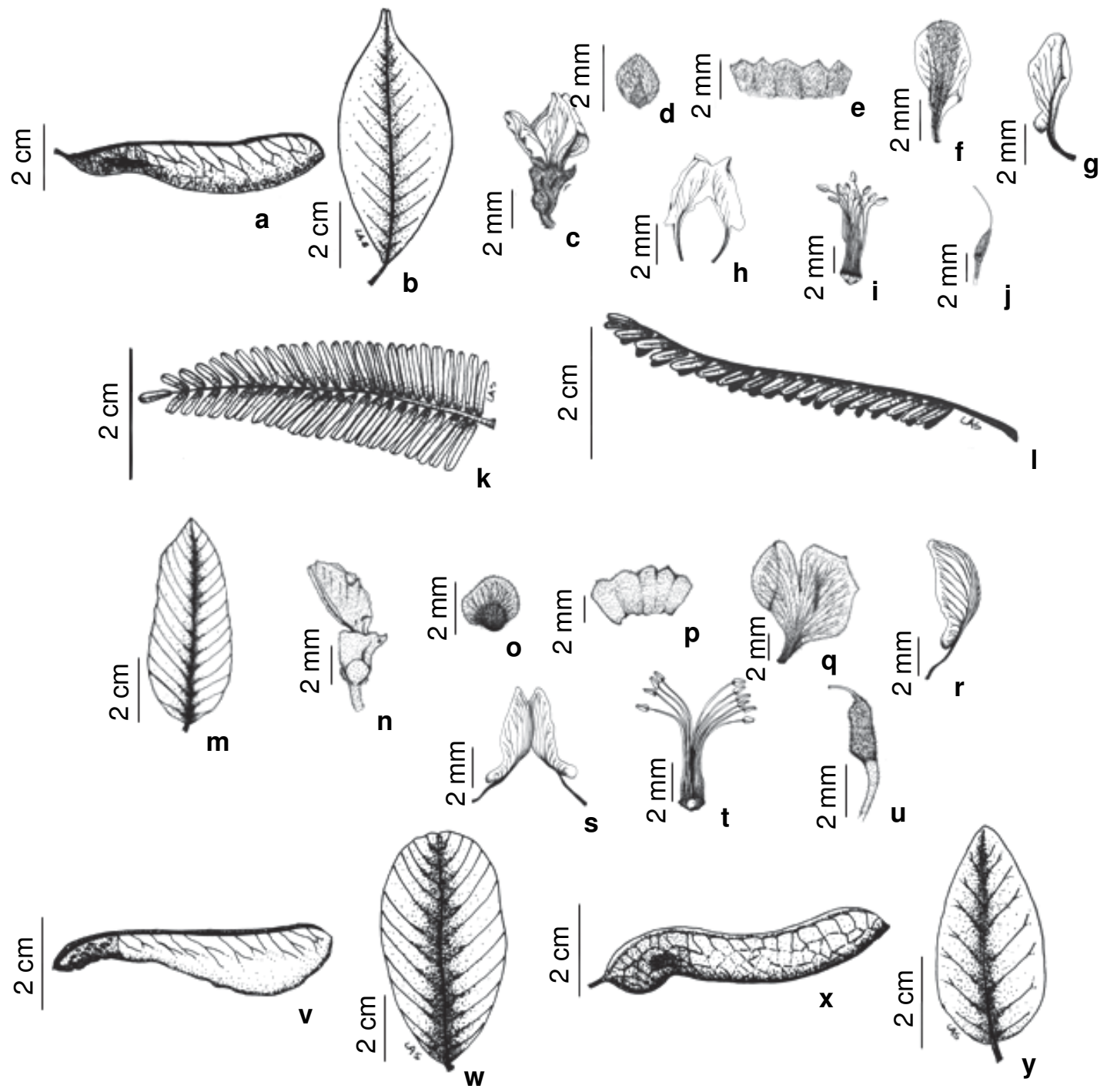

Figura 2 - a-j. Machaerium macrophyllum var. macrophyllum (a-b Pereira 396; c-j Hatschbach 67004) - a. fruto; b. folíolo, face adaxial; c. flor; d. bractéola; e. cálice; f. estandarte; g. asa; h. pétalas da quilha; i. androceu; j. gineceu. k. M. multifoliolatum (Philcox 4191) - folha, face adaxial. 1. M. pilosum (Silva 3374) - folha, face adaxial. m-u. M. quinatum var. quinatum (m-u Thomas s/n) - m. folíolo, face adaxial; n. flor; o. bractéola; p. cálice; q. estandarte; r. asa; s. pétalas da quilha; t. androceu; u. gineceu. v-x. M. quinatum var. parviflorum (v-x Mattos 15530) - v. fruto; w. folíolo, face adaxial. x-y. M. stipitatum (w-y Arruda 152) - x. fruto; y. folíolo, face adaxial.

Figure 2 - a-j. Machaerium macrophyllum var. macrophyllum (a-b Pereira 396; c-j Hatschbach 67004) - a. fruit; b. leaflet, adaxial surface; c. flower; d. bracteole; e. calyx; f. standard; g. wing; h. petals of the keel; i. androecium; j. gynoecium. k. M. multifoliolatum (Philcox 4191) - leaf, adaxial surface. 1. M. pilosum (Silva 3374) - leaf, adaxial surface. m-u. M. quinatum var. quinatum (m-u Thomas $s / n)$ - m. leaflet, adaxial surface; n. flower; o. bracteole; p. calyx; q. standard; r. wing; s. petals of the keel; t. androecium; u. gynoecium. v-x. M. quinatum var. parviflorum (v-x Mattos 15530) - v. fruit; w. leaflet, adaxial surface. x-y. M. stipitatum (w-z Arruda 152) - x. fruit; y. leaflet, adaxial surface. 
androceu monadelfo, filetes de alturas diferentes, anteras oblongas; ovário velutino, estigma clavado. Sâmaras falciformes, estipe viloso, 4-6 mm compr., região seminífera tomentosa a glabrescente, castanho-clara, 1-2×0,5-1 cm, asa tomentosa a glabrescente, elíptica, amarelada, 2,5-4×1-1,5 cm.

Material selecionado: MATO GROSSO: Chapada dos Guimarães, 19.IX.1988, fr., M. Pereira 396 (RB). Nova Xavantina, 25.IX.1949, fr., J.E. Oliveira s/n (RB 67959). Poxoréu, 30.X.1976, fr., M. Macedo et al. 276 (INPA). Vila Bela da Santíssima Trindade, 18.VIII.1997, fl., G. Hatschbach et al. 67004 (RB).

Machaerium macrophyllum var. macrophyllum apresenta estípulas não modificadas em espinhos, a maioria dos folíolos oblongolanceolados, com manchas vináceas na face adaxial, cálice externamente viloso, corola vinácea e estandarte largo-elíptico, denso-tomentoso. A sâmara não reniforme, provida de ala desenvolvida (5-6×1,5-2 cm), diferencia a var. macrophyllum da var. brevialatum Rudd, caracterizada por sâmara reniforme com ala terminal curta $(2,5-3 \times 3,4 \mathrm{~cm})$ (Rudd 1972, 1987). A variedade típica possui registros para as regiões central e Sul de Mato Grosso, sendo esta a primeira citação para o Estado. Habita Florestas Ombrófilas Aberta e Densa. Floresce em agosto e frutifica em setembro e outubro.

12. Machaerium multifoliolatum Ducke, Bull. Mus. Natl. Hist. Nat., sér. 24(6): 734. 1932. Fig. 2 k

Arbustos escandentes; ramos pubescentes; espinhos recurvados, ca. $2 \mathrm{~mm}$ compr.; lenticelas inconspícuas, exsudado amarronzado. Folhas 75102-folioladas; pecíolo tomentoso, raramente setoso, 1,5-2,5 mm compr., raque setoso, 8-11,5 cm compr.; folíolos sésseis, opostos, concolores, glabros, estreito-oblongos ou estreito-elípticos, os apicais obovados, base oblíqua, ápice retuso, nervação craspedódroma, $0,5-1,5 \times$ ca. $0,2 \mathrm{~cm}$. Panículas terminais, eixos tomentosos. Flores pediceladas; bractéolas tomentosas, orbiculares, ca. $1 \mathrm{~mm}$ compr.; cálice campanulado, tomentoso, região mediana glabra, ca. $2 \mathrm{~mm}$ compr.; corola branca; estandarte externamente pubescente, ca. 5 mm compr.; asa e pétalas da quilha glabras, ca. 5 mm compr.; androceu monadelfo, filetes de mesma altura, anteras oblongas; ovário tomentoso, estigma clavado. Sâmaras cultriformes, estipe tomentoso, ca. $0,5 \mathrm{~mm}$ compr; região seminífera tomentosa, ca. $2,5 \mathrm{~cm}$ compr, asa tomentosa, ca. $4 \times 0,5 \mathrm{~cm}$ (Bastos 1981).

Material examinado: MATO GROSSO: Nova Xavantina, 25.I.1968, D. Philcox \& A. Ferreira 4191 (UB).
Machaerium multifoliolatum é reconhecida pelo número elevado de folíolos (75-102), não ultrapassando $1,5 \mathrm{~cm}$ compr. Foi registrada apenas no extremo leste de Mato Grosso, em Floresta Ombrófila Densa. Não possui dados sobre floração e frutificação.

13. Machaerium paraguariense Hassl., Bull. Herb. Boissier, sér. 2, 7: 358. 1907.

Arvoretas a árvores, 2-20 m alt.; ramos glabrescentes; estípulas não modificadas em espinhos; lenticelas esbranquiçadas, exsudado não observado. Folhas 5-7-folioladas; pecíolo, raque e peciólulo vilosos, pecíolo 2-4 cm compr., raque 24,5 cm compr., peciólulo 2,5-5 mm compr.; folíolos peciolados, alternos ou subopostos, concolores, glabros, esparso-tomentosos apenas sobre a nervura principal da face abaxial, ovados ou largoovados, raramente largo-elípticos, base arredondada, ápice cuspidado, raramente acuminado, nervação broquidódroma, 4,5-6 × 2,5$5 \mathrm{~cm}$. Racemos em fascículos, axilares, eixos vilosos, o principal 5-6,5 cm compr. Flores sésseis; bractéolas internamente glabras, externamente tomentosas, ovadas ou largo-ovadas, 2,5-3 $\times 2-$ 2,5 mm, cálice campanulado, glabro, externamente tomentoso no ápice, lacínios superiores largoelípticos, os inferiores elípticos, ca. 4 mm compr.; corola alva ou creme-esverdeada; estandarte ventralmente glabro, dorsalmente tomentoso, largoovado ou ovado, raramente obovado, ápice obtuso ou retuso, ca. $6,5 \times 6 \mathrm{~mm}$; asa e pétalas da quilha glabras, elípticas, asa ca. $7 \times 3 \mathrm{~mm}$, pétalas da quilha ca. $7,5 \times 3 \mathrm{~mm}$, androceu monadelfo, filetes de alturas diferentes, anteras ovadas, às vezes triangulares; ovário esparso-velutino, estigma clavado. Sâmaras falciformes, estipe viloso, 6,59,5 mm compr., região seminífera tomentosa a glabrescente, castanho-escura, 1-2 × 1-1,5 cm, asa tomentosa a glabrescente, oblonga, castanhoclara, 3,5-4,5×1-1,5 cm.

Material selecionado: MATO GROSSO: Alta Floresta, II.1988, fr., S. Assumpção s/n (CH). Barra do Garças, 25.VIII.1972, fr., J.A. Ratter et al. $s / n$ (UB). Cáceres, 1997, fr., F. Dário et al. s/n (ESA 61804). Juscimeira, 16.IX.1995, fr., A. Pott et al. 7294 (CGMS, CPAP). Poconé, 7.X.1989, fl. e fr., A. Pott 5083 (CPAP, HMS); 12.XI.2005, fr., A. Pott \& V.J. Pott 13559 (HMS). Rondonópolis, 15.IX.1995, fr., S.M. Salis et al. 826 (CGMS, CPAP). MATO GROSSO DO SUL: Bonito, XI.1997, fl., U.M. Resende 2006 (CGMS). Corumbá, 24.II.1988, fr., A. Pott et al. 474 (CGMS, CPAP). Miranda, 20.X.1991, fr., U.M. Resende 563 (CGMS). Nioaque, II.2001, fl., R.J. Bastos 798 (CGMS). 
Material adicional selecionado: PARAGUAI. YPACARAI: 1.1845-1895, fl., E. Hassler 1849 (holótipo G).

Caule e ramos esfoliantes (Sartori \& Tozzi 1998), folíolos geralmente ovados ou largo-ovados, com ápice em geral cuspidado, e inflorescência racemosa são características diagnósticas de $M$. paraguariense. Em Mato Grosso do Sul, está distribuída na região noroeste, especialmente no Alto Pantanal. Este é o primeiro registro para o Mato Grosso, tendo sido encontrada na região sul e extremo norte do Estado. Ocorre preferencialmente em Florestas Estacionais Decidual e Semidecidual e Savana (Cerrado). Floresce em outubro e novembro e frutifica de outubro a fevereiro.

14. Machaerium pilosum Benth., J. Linn. Soc., Bot. 4(Suppl.): 57.1860.

Fig. 21

Lianas escandentes; ramos puberulentos; espinhos retilíneos, 1-1,5 mm compr.; lenticelas enegrecidas, exsudado não observado. Folhas 4757 folioladas; pecíolo, raque e peciólulo vilosos, pecíolo ca. $3 \mathrm{~mm}$ compr., raque $8-9,5 \mathrm{~cm}$ compr., peciólulo ca. $1 \mathrm{~mm}$ compr.; folíolos alternos, discolores, glabrescentes na face adaxial, com resinas amarelas, seríceos a glabrescentes na face abaxial, margem tomentosa, elípticos ou estreito-elípticos, base arredondada ou oblíqua, ápice agudo, nervação craspedódroma, 7-9×1,5-3 cm. Panículas terminais, eixos vilosos, o principal ca. $18 \mathrm{~cm}$ compr. Flores pediceladas; bractéolas tomentosas, largo-ovadas, 10-20 mm compr., cálice cilíndrico, glabrescente, 40$50 \mathrm{~mm}$ compr.; estandarte ventralmente glabro, dorsalmente puberulento, 100-120 mm compr; asa 80-100 mm compr., pétalas da quilha 80-100 mm compr.; androceu monadelfo, filetes de mesma altura; ovário densamente tomentoso (Bastos 1981). Sâmaras imaturas, cultriformes; estipe 0,5-1,0 cm compr., região seminífera ca. $1,5 \mathrm{~cm}$ compr, asa ca. 3 $\times 0,5-1 \mathrm{~cm}$ (Bastos 1981).

Material examinado: MATO GROSSO: s/loc., 18.VII.1977, fl. e fr., M.G. Silva \& J. Maria 3374 (RB).

Machaerium pilosum pode ser identificada pelos espinhos retilíneos e diminutos (1-1,5 mm compr.), pecíolo, raque e peciólulo vilosos e folíolos de margem tomentosa. Bastos (1987) descreveu $M$. pilosum como arbórea, enquanto o material aqui analisado apresenta hábito escandente, semelhante ao observado por Hoehne (1941). O hábito escandente a difere de $M$. eriocarpum e $M$. hirtum, duas espécies arbóreas. O hábito e a morfologia geral dos folíolos, por outro lado, aproximam $M$. pilosum, M. aculeatum e M. isadelphum; nas últimas duas espécies, no entanto, os espinhos são recurvados, ao passo que, em $M$. pilosum, eles são retilíneos. A espécie é registrada para Mato Grosso, mas sem indicação de localidade na etiqueta de herborizado. Ocorre em Floresta Ombrófila Densa Aluvial. Foi coletada em julho, final de floração, com frutos imaturos.

15. Machaerium quinatum (Aubl.) Sandwith var. quinatum, Bull. Misc. Inform. Kew 1931(7): 359. 1931.

Fig. $2 \mathrm{~m}-\mathrm{u}$

Arvoretas 3-5 m alt.; ramos pubescentes; estípulas não modificadas em espinhos; lenticelas inconspícuas, exsudado acastanhado. Folhas 1113-folioladas; pecíolo e raque pubescentes a tomentosos, pecíolo 2,5-5 cm compr., raque 9,5-14,5 cm compr., peciólulo tomentoso, 2-3,5 mm compr.; folíolos peciolados, alternos ou subopostos, discolores, puberulentos na face adaxial, vilosos a glabrescentes na abaxial, lanceolados ou oblongolanceolados, base equilateral, ápice agudo ou acuminado, nervação craspedódroma, 6-10×2-3,5 $\mathrm{cm}$. Racemos axilares ou terminais, eixos vilosos, o principal 12,5-18 cm compr. Flores pediceladas, pedicelos vilosos, ca. $1 \mathrm{~mm}$ compr.; bractéolas internamente glabras, externamente vilosas, largoovadas ou ovado-comprimidas, 2,5-3,5 ×2-2,5 mm; cálice cilíndrico, internamente glabro, externamente tomentoso a glabrescente, lacínios superiores largoelípticos, inferiores elípticos, 3,5-4 mm compr.; corola enegrecida; estandarte ventralmente glabro, dorsalmente seríceo, obovado ou largo-obovado, ápice retuso, ca. $10 \times 8,5 \mathrm{~mm}$; asa e pétalas da quilha glabras, elípticas, asa ca. $10,5 \times 4 \mathrm{~mm}$, pétalas da quilha 9-10 × ca. $3 \mathrm{~mm}$; androceu monadelfo, filetes de mesma altura, anteras oblongas, às vezes triangulares; ovário velutino, estigma capitado. Sâmaras falciformes, hirsutas, amareladas, 6-9,5 × 2-2,5 cm (Lozano \& Klitgaard 2006).

Material examinado: MATO GROSSO: Nova Suia, 14.VIII.1997, fl., L. C. Bernacci 2449 (ESA, IAC). Sinop, 31.X.1985, fl., W. Thomas et al. s/n (INPA 150676).

Machaerium quinatum var. quinatum apresenta folíolos oblongo-lanceolados ou lanceolados, inflorescência racemosa, cálice cilíndrico e corola enegrecida. $\mathrm{O}$ hábito arvoreta e os folíolos vilosos ou glabrescentes na face abaxial aproximam este táxon de $M$. quinatum var. parviflorum. Os folíolos são lanceolados ou oblongo-lanceolados, de ápice agudo ou acuminado, e o cálice cilíndrico na variedade típica, enquanto, na var. parviflorum, os folíolos são 
elípticos ou largo-elípticos, de ápice arredondado ou obtuso, e o cálice é campanulado. Trata-se da primeira citação deste táxon para o Mato Grosso, ocorrendo na região norte, em Floresta Ombrófila Densa. Foram observadas flores de agosto a outubro, mas não foram obtidos dados de frutificação.

\section{Machaerium quinatum var. parviflorum} (Benth.) Rudd, Phytologia 24(2): 121. 1972.

Fig. $2 \mathrm{v}-\mathrm{w}$

Arvoretas ca. 2,5 m alt.; ramos puberulentos a pubescentes; estípulas não modificadas em espinhos; lenticelas inconspícuas, exsudado não observado. Folhas 9-11-folioladas; pecíolo e raque pubescentes, pecíolo 1,5-2,5 cm compr., raque 5,5$7 \mathrm{~cm}$ compr., peciólulo tomentoso, 2-3 mm compr.; folíolos peciolados, alternos, discolores, face adaxial glabra, face abaxial glabrescente, tomentosa apenas sobre a nervura principal, elípticos ou largoelípticos, base arredondada, ápice arredondado ou obtuso, nervação craspedódroma, $3,5-5 \times 2-3 \mathrm{~cm}$. Panículas axilares ou terminais, eixos ferrugíneotomentosos. Flores pediceladas; bractéolas ovadas ou elípticas, ca. $1 \times 1,5 \mathrm{~mm}$; cálice campanulado, ferrugíneo-seríceo, 3-4,5 mm compr.; corola alva ou amarelada; estandarte pubescente (Rudd 1972). Estandarte, asas, pétalas da quilha, androceu e gineceu não observados. Sâmaras falciformes, estipe velutino, 5,5-7,5 mm compr., região seminífera tomentosa, castanho-clara, 1,5-2,5 × 0,5-1 cm, asa tomentosa a glabrescente, elíptica, amarelada, 4,5-6×1-2 cm.

Material examinado: MATO GROSSO: Luciara, 15.XII.1969, fr., J. Mattos 15530 (SP).

Machaerium quinatum var. parviflorum caracteriza-se pelas estípulas não modificadas em espinhos, folíolos elípticos ou largo-elípticos, com nervuras secundárias proeminentes, cálice campanulado e asa da sâmara amarelada. Esta variedade é citada pela primeira vez para o Mato Grosso, ocorrendo no extremo da região nordeste do estado. Ocorre em Floresta Estacional Decidual. Não foram observadas flores, mas os frutos foram encontrados em dezembro.

\section{Machaerium stipitatum (DC.) Vogel, Linnaea} 11: 189. 1837.

Fig. $2 x-y$

Árvores ca. $7 \mathrm{~m}$ alt.; ramos glabrescentes; estípulas não modificadas em espinhos; lenticelas esbranquiçadas, exsudado não observado. Folhas 911 folioladas; pecíolo tomentoso a glabrescente, 0,5 $2,5 \mathrm{~cm}$ compr.; raque e peciólulo vilosos a glabrescentes, raque 3-6,5 cm compr., peciólulo 2-3 mm compr.; folíolos peciolados, alternos, discolores, glabros na face adaxial, esparso-pubescentes na face abaxial, vilosos sobre a nervura principal, oblongo-elípticos ou oblongo-lanceolados, base arredondada, ápice arredondado, nervação broquidódroma, 2,5-5×1-2 $\mathrm{cm}$. Panículas terminais, axilares, eixos esparsamente ferrugíneo-tomentosos. Flores sésseis; bractéolas externamente pubérulas a tomentelas, oblongas, ca. $1 \mathrm{~mm}$ compr.; cálice campanulado, externamente esparso e curto-tomentoso, ca. $2 \mathrm{~mm}$ compr.; corola creme ou esverdeada; estandarte dorsalmente seríceo, amplamente obovado; ca. $5 \times 3 \mathrm{~mm}$; asa e pétalas da quilha glabras, oblongas, asa ca. $5 \mathrm{~mm}$ compr., pétalas da quilha ca. $4 \mathrm{~mm}$ compr.; androceu monadelfo, filetes de mesma altura, anteras oblongo-arredondadas; ovário esparso-viloso no ápice (Sartori \& Tozzi 1998). Sâmaras falciformes; estipe esparso-tomentoso a esparso-pubescente, 4-7 mm compr., região seminífera glabra, marrom, $1-2 \times 0,5-1 \mathrm{~cm}$, asa glabra, elíptica, castanho-clara, $2-3,5 \times 0,5-1,5 \mathrm{~cm}$.

Material selecionado: MATO GROSSO DO SUL: Anaurilândia, 18.VI.1998, fr., J.L.G. Salvador et al. 1 (CGMS). Corumbá, 31.III.2003, fr., M.C.V. Arruda et al. $152(\mathrm{CH})$.

Machaerium stipitatum pode ser identificada pelo hábito arbóreo, folíolos oblongo-elípticos ou oblongo-lanceolados, de ápice arredondado e nervação broquidódroma, e sâmara com asa elíptica, castanho-clara. Ocorre no extremo da região noroeste e sudeste de Mato Grosso do Sul, em Floresta Estacional Semidecidual. Sua floração não foi observada, mas frutos foram encontrados em março e junho.

18.Machaerium villosum Vogel,Linnaea 11: 189. 1837. Árvores 4-8 m alt.; ramos vilosos a glabrescentes; estípulas não modificadas em espinhos; lenticelas amareladas, exsudado amarronzado. Folhas 19-25 folioladas; pecíolo viloso a glabrescente, 2-4,5 cm compr.; raque e peciólulo vilosos, raque 19-29,5 cm compr., peciólulo 2,5-5 mm compr.; folíolos peciolados, alternos ou subopostos, concolores, velutinos a esparso-velutinos, lanceolados ou oblongo-lanceolados, base arredondada ou equilateral, ápice agudo ou acuminado, nervação broquidódroma, 6-9×1-3 cm. Panículas axilares, eixos vilosos, os de segunda ordem fasciculados, o principal $12-14,5 \mathrm{~cm}$ compr. Flores sésseis; bractéolas internamente glabrescentes, externamente tomentosas, largo-ovadas ou ovadocomprimidas, 1-2 $\times 1-1,5 \mathrm{~mm}$; cálice campanulado, internamente glabrescente, externamente tomentoso a glabrescente, tomentoso sobre ápice, lacínios 
superiores oblongos, inferiores estreito-oblongos, 2,5$3 \mathrm{~mm}$ compr.; corola alva; estandarte ventralmente glabro, dorsalmente seríceo, ovado ou largo-ovado, ápice obtuso ou retuso; ca. 7,5 $\times 5,5 \mathrm{~mm}$; asa e pétalas da quilha glabras, asa tomentosa na região da unguícula, elíptica, $6,5-8 \times 2,5-3 \mathrm{~mm}$; pétalas da quilha oblongas, ca. $7,5 \times 3 \mathrm{~mm}$; androceu monadelfo, filetes de mesma altura, anteras oblongas ou triangulares; ovário velutino, estigma capitado. Sâmaras cultriformes; estipe glabrescente, $0,5-1,5 \mathrm{~mm}$ compr., região seminífera glabra, marrom, brilhante, 1,5-3×1$2 \mathrm{~cm}$, asa glabrescente, elíptica, castanho-clara, $4-5 \times$ $1,5-2 \mathrm{~cm}$.

Material selecionado: MATO GROSSO DO SUL: Bodoquena, 25.VIII.2002, fr., U.M. Resende \& S. Aragaki 1208 (CGMS, DDMS); 19.VIII.2006, C.A. Polido et al. 16 (CGMS). Bonito, IX.1998, fr., G.A. Damasceno Junior et al. 1621 (CGMS); 9.X.2003, fl., G. Hatschbach et al. 76049 (MBM, SPSF). Corumbá, 28.X.1980, fl. e fr., J.E. Guimarães 1237 (RB); 30.IX.1996, fl., A. Pott 7880 (CPAP, HMS).

Material adicional selecionado: s/loc., s/d, fl., F. Sellow $s / n$ (isótipo $\mathrm{K} n . v$., foto UEC).

Machaerium villosum caracteriza-se pela raque e peciólulo vilosos, folíolos lanceolados ou oblongolanceolados, velutinos a esparso-velutinos em ambas as faces, e flores sésseis, de corola alva. A espécie é encontrada no Mato Grosso do Sul, na porção noroeste do Estado, em Savana (Cerrado) e Floresta Estacional Semidecidual. Floresce em setembro e outubro, sendo observados frutos em agosto e setembro.

\section{Agradecimentos}

Aos curadores dos herbários o empréstimo das exsicatas; às biólogas Caroline Leuchtenberger e Luciana A. Spindola, as ilustrações; à FUNDECT (Fundação de Apoio ao Desenvolvimento do Ensino, Ciência e Tecnologia do Estado de Mato Grosso do Sul) a bolsa de Mestrado concedida à primeira autora; à coordenação do Mestrado em Biologia Vegetal da UFMS e à Pró-Reitoria de Pesquisa e Pós-Graduação, o auxílio às excursões de campo.

\section{Referências}

Barroso, G.M.; Morim, M.P.; Peixoto, A.L. \& Ichaso, C.L.F. 1999. Frutos e sementes: morfologia aplicada à sistemática de dicotiledôneas. Universidade Federal de Viçosa, Viçosa. 443p.

Bastos, M.N.C. 1987. Contribuição ao estudo de algumas espécies do gênero Machaerium Persoon (Leguminosae - Papilionoideae) ocorrentes na Amazônia brasileira. Boletim do Museu Paraense Emílio Goeldi, série Botânica 3: 183-278.
Bentham, G. 1862. Leguminosae. Dalbergieae. In: Martius C.P.F. \& Eichler, A.G.(eds.). Flora brasiliensis. F. Fleisher, Lipsiae. Vol. 15. Pars. 1. 349p.

Borges, H.B.N \& Shepherd, G.J. 2005. Flora e estrutura do estrato lenhoso numa comunidade de Cerrado em Santo Antônio do Leverger, MT, Brasil. Revista Brasileira de Botânica 28: 61-74.

Bortoluzzi, R.L.C.; Carvalho-Okano, R.M.; Garcia, F.C.P. \& Tozzi, A.M.G.A. 2004. Leguminosae, Papilionoideae no Parque Estadual do Rio Doce, Minas Gerais, Brasil. II: árvores e arbustos escandentes. Acta Botanica Brasilica 18: 49-71.

Camargo, R.A. 2005. A Tribo Dalbergieae (LeguminosaeFaboideae) no Estado de Santa Catarina, Brasil. Dissertação de Mestrado. Universidade Federal do Rio Grande do Sul, Porto Alegre. 131p.

Damasceno Junior, G.A.; Nakajima, J.N. \& Rezende, U.M. 2000. Levantamento florístico das cabeceiras dos rios Negro, Aquidauana, Taquari e Miranda no Pantanal, Mato Grosso do Sul, Brasil. In: Willink, P.W.; Chernoff, B.; Alonso, L.E.; Montambault, J.R. \& Lourival, R. (eds.). Uma avaliação biológica dos ecossistemas aquáticos do Pantanal, Mato Grosso do Sul, Brasil. Conservation International, Washington, DC. Pp. 152-162.

Daniel, O. \& Arruda, L. 2005. Fitossociologia de um fragmento de floresta estacional semidecidual aluvial às margens do rio Dourados, MS. Scientia Forestalis 68: 69-86.

Dubs, B. 1998. Prodomus florae matogrossensis. Betrona Verlag, Kusnacht. 444p.

Font Quer, P.1953. Diccionario de botánica. Labor S.A., Barcelona. 1244p.

Harris, J.G. \& Harris, M.W. 1994. Plant identification terminology: an illustrated glossary. Spring Lake Publishing, Spring Lake. 198p.

Hickey, L.J. 1973. Classification of the architecture of dicotyledonous leaves. American Journal of Botany 60 : 17-23.

Hoehne, F.C. 1941. Leguminosas Papilionadas - gêneros Machaerium e Paramachaerium. In: Flora brasilica. São Paulo. Vol. 25. Fasc.3. 100p.

Holmgren, P.K. \& Holmgren. 1998. Onwards (continuously update). Index herbarium. New York Botanical Garden, New York. Disponível em <http.//sciweb.nybg.org/ science2/indexherbarium.asp $>$ Acesso em agosto 2006.

IBGE. 1992. Manual técnico da vegetação brasileira. Fundação Instituto Brasileiro de Geografia e Estatística, Rio de Janeiro. 89p.

Lewis, G.P. 1987.Legumes of Bahia. Royal Botanic Gardens, Kew. 369p.

Lewis, G.P.; Schire, B.; Mackinder, B. \& Lock, M. 2005. Legumes of the world. Royal Botanic Gardens, Kew. $577 \mathrm{p}$.

Lima, H.C. 1995. Leguminosas da Flora Fluminenses-J.M.C. Velloso - Lista atualizada das espécies arbóreas. Acta Botanica Brasilica 9: 123-146. 
Lima, H.C.; Correia, C.M.B. \& Farias, D.S. 1994. Leguminosae. In: Lima, M.P.M. \& Guedes-Bruni, R.R. (orgs.). Reserva Ecológica de Macaé de Cima, Nova Friburgo-RJ: aspectos florísticos das espécies vasculares. Vol. 1. Jardim Botânico do Rio de Janeiro, Rio de Janeiro. 404p.

Lima, L.C.P.; Garcia, F.C.P. \& Sartori, A.L.B. 2007. Leguminosae Adans. nas florestas estacionais do Parque Estadual do Itacolomi, Minas Gerais, Brasil: ervas, arbustos, subarbustos, lianas e trepadeiras. Rodriguésia 58: 331-358.

Lorenzi, H. 1992. Árvores brasileiras: manual de identificação e cultivo de plantas arbóreas nativas do Brasil. Vol. 1. Plantarum, Nova Odessa. 368p.

Lorenzi, H. 1998. Árvores brasileiras: manual de identificação e cultivo de plantas arbóreas nativas do Brasil. Plantarum, Nova Odessa. Vol. 2. 368p.

Lozano, P. \& Klitgaard, B.B. 2006. The genus Machaerium (Leguminosae: Papilionoideae: Dalbergieae) in Ecuador. Brittonia 58: 124-150.

Marimon, B.S. \& Lima, E.S. 2001. Caracterização fitofisionômica e levantamento florístico preliminar no pantanal dos rios Mortes-Araguaia, Cocalinho, Mato Grosso, Brasil. Acta Botanica Brasilica 15: 213-229.

Mendonça-Filho, C.V. 1996. Braúna, angico, jacarandáe outras leguminosas de Mata Atlântica: Estação Biológica de Caratinga, Minas Gerais. Fundação Botânica Margaret Mee, Viçosa. 100p.

Mendonça-Filho, C.V.; Forni-Martins, E.R. \& Tozzi, A.M.G.A. 2002. New chromosome counts in neotropical Machaerium Pers. species (Fabaceae) and their taxonomic significance. Caryologia 55: 111-114.

Mendonça-Filho, C.V.; Tozzi, A.M.G.A \& Forni-Martins, E.R. 2007. Revisão taxonômica de Machaerium sect.
Oblonga (Benth.) Taub. (Leguminosae, Papilionoideae, Dalbergieae). Rodriguésia. 58: 283-312.

Pinto, J.R.R. \& Hay, J.V. 2005. Mudanças florísticas e estruturais na comunidade arbórea de uma floresta de vale no Parque Nacional da Chapada dos Guimarães, Mato Grosso, Brasil. Revista Brasileira de Botânica 28: 523-539.

Pinto, J.R.R \& Oliveira-Filho, A.T. 1999. Perfil florístico e estrutura da comunidade arbórea de uma floresta de vale no Parque Nacional da Chapada dos Guimarães, Mato Grosso, Brasil. Revista Brasileira de Botânica 22: 53-67.

Polido, C.A. \& Sartori, A.L.B. 2007. O gênero Machaerium (Leguminosae-Papilionoideae-Dalbergieae) no Pantanal brasileiro. Rodriguésia 58: 313-329.

Pott, A. \& Pott, V.J. 1994. Plantas do Pantanal. Embrapa, Brasília. 320p.

Radford, A.E.; Dickison, W.C.; Massey, J.R. \& Bell, C.R. 1974. Vascular plant systematics. Harper \& Row, New York. 891p.

Rudd, V.E. 1972. New taxa and combinations in Machaerium (Leguminosae). Phytologia 24: 121-124.

Rudd, V.E. 1987. Studies in Machaerium (Leguminosae) VI. Phytologia 62: 282-302.

Salis, S.M.; Silva, M.P.; Mattos, P.P.; Silva, J.S.V.; Pott, V.J. \& Pott, A. 2004. Fitossociologia de remanescentes de floresta estacional decidual em Corumbá, Estado do Mato Grosso do Sul, Brasil. Revista Brasileira de Botânica 27: 671-684.

Sartori, A.L.B. \& Tozzi, A.M.G.A. 1998. As espécies de Machaerium Pers. (Leguminosae - Papilionoideae Dalbergieae) ocorrentes no estado de São Paulo. Revista Brasileira de Botânica 21: 211-246.

\section{Lista de Exsicatas}

Amador, G.A. 11 (13). Aragaki, S. 985 (8). Arbócz 3472 (7); 3690, 3777 (2); 3811 (3); 4071 (2); 4612 (9). Arruda, M.C.V. 152 (17). Bastos, R.J. 798 (13). Bernacci, L.C. 2449 (15). Bezerra, M.A.O. 7 (6). Borges, J.R. 137 (5). Caliente, A.D. 1626 (6). Carreira, L. 670 (3). Carvalho, C.A. 2737 (6). Cesar, O. 322 (2). Conceição, D.N. s/n RB 295194 (6). Constantino, R. 130 (8). Cordeiro, I. 9680 , 1196 (2). Costa, J.S. 148 (6); 157 (6). Cunha, C.N. 4613 (6). Damasceno-Júnior, G.A. 1621 (18); 2763 (8); 2816 (1). Dário, F.R. 1149 (3); s/n. ESA 61804 (13). Dubs, B 1571 (2). Falcão, C.T. 5125 (9). Faria, S.M. 1420 (6). Fernandes-Júnior, S. 113 (3). Ferrucci, M.S. 1472 (2); Garcez, W.S. s/n CGMS 05172 (2). Gomes-Júnior, J.C. 1988 (8). Guimarães, J.G. 1237 (18); 1301 (6). Harley, R.M. 10930, 11300 (2). Hassler, E. 1849 (13). Hatschbach, G. 37488,52427 (2); 52446 (3); 52465 (6); 58552 (8); 58886 (2); $62210,62489,62497$ (4); 62635 (3); 65479 (2); 67004 (11); 76049 (18); 77453 (6). Hoehne, F.C. 272 (10); 2550 (3). Jacques, E.L. 960 , 1658 (2). Kuhlmam, J.G. 426 (2). Lehn, C.R. s/n. CGMS 17592 (10). Lescano, L.E. 209 (6). Lima, A. 3153 (3). Loureiro, R.L. 26 (6). Macedo, M. 63 (3); 276 (11); 1356 (6); s/n INPA 164601 (1); s/n INPA 176628 (3). Maciel, A.A. 179 (3). Maria, V.R. 339 (6). Mattos, J. 15530 (16); 15535 (9). Melo, P.H.A. 115 (6). Nadruz, M. 1259 (1). Nave, A.G. 1193 (2); 1333 (3); 2172 (5). Nunes, M.S. 17 (2). Oliveira, J.E. s/n. RB 67959 (11). Pastore, U. 132 (2). Pereira, M. 396 (11). Pereira-Noronha, M.R. 478 (2). Philcox, D. 3017,3570 (2); 4191 (12). Pinto, J.R.R. 76 (5). Polido, C.A. 16 (18); 17 (8). Pott, A. 474 (13); 1904, 1942 (3); 2238 (2); 3267 (6); 3418 (8); 3430 (2); 3508 (8); 3806 (13); 4228 , 4282 (8); 4773 (3); 4990 (10); 5083 (13); 6616, 7065 (2); 7095 (8); 7294 (13); 7734 (2); 7880 (18); 9523 (8); 10500 (2); $10744(8) ; 10860$ (6); 13559 (13). Prance, G.T. 26676, s/n INPA 42461 (2). Ramos, A.E. 222 , 263, 288, 309, 362 (2). Ramos, J. s/n RB 164375 (2). Ratter, J.A. s/n RB 165756, UB 2053, UB 4552 (2); s/n UB 5241, UB 7070, UB 7670 (6). Resende, U.M. 163 (3); 262 (2); 360 (6); 563 (13), 1208 (18); 2006 (13); s/n CGMS 2142 (2). Ribas, O.S. 2450 (8). Ribeiro, E. 9 (3). Salis, S.M. 826 (13); 908 (5). Salvador, J.L.G. 1 (17); 50 (8). Santos, J.U. 563 (6); 611 (6); Sartori, A.L.B. 475 (6); 921 (2); s/n. CGMS 17586 (10). Schwenk, L.M. 42 (3). Sciamarelli, A. 770 (2); 846 (8); 919 (3); 998 (2); 1344 (8). Shepherd, G.J. 7511 (3). Silva, M.G. 3374 (14); 4423 (2). Silva, R.R. 623 (8); 1120 , 1329 (1). Souza, P.R. s/n CGMS 11425 (1). Souza, V.C. 15520 (3); 16185,16687 (2); 16752 (3); 20505 (2). Torres, A.C. 10 (2). Thomas, W. s/n. INPA 150676 (15). Valls, J.F.M. 7649 (6). 